\title{
Bone Morphogenetic Protein Receptor Type-1B
}

National Cancer Institute

\section{Source}

National Cancer Institute. Bone Morphogenetic Protein Receptor Type-1B. NCI

Thesaurus. Code C73561.

Bone morphogenetic protein receptor type-1B (502 aa, $\sim 57 \mathrm{kDa}$ ) is encoded by the human BMPR1B gene. This protein is a receptor serine/threonine kinase and is involved in signal transduction. 